\title{
Activated B Cells from Patients with Common Variable Immunodeficiency Proliferate and Synthesize Immunoglobulin
}

\author{
Shigeaki Nonoyama, * Mary Farrington, * Hiroshi Ishida, ${ }^{\ddagger 5}$ Maureen Howard, ${ }^{*}$ and Hans D. Ochs * \\ * Department of Pediatrics, University of Washington, Seattle, Washington 98195; ${ }^{\ddagger}$ DNAX Research Institute, Palo Alto, California \\ 94304; and ${ }^{\S}$ rd Department of Internal Medicine, Wakayama Red Cross Hospital, Wakayama 640, Japan
}

\begin{abstract}
Most patients with common variable immunodeficiency (CVI) have normal numbers of circulating $B$ cells but low concentrations of serum Ig. To determine if the hypogammaglobulinemia is caused by an intrinsic $B$ cell defect, we studied $B$ cell function of 22 CVI patients. Cultured B cells from all CVI patients underwent normal proliferation and synthesized normal quantities of IgE in the presence of anti-CD40 and IL-4. If cultured with anti-CD40 and IL-10, four patterns of Ig isotype synthesis were observed. Six CVI patients produced normal amounts of IgM, IgG, and IgA. Four patients produced normal quantities of IgM and IgG. Of the remaining 12 patients who failed to synthesize IgG and IgA, 8 produced normal and 4 synthesized decreased amounts of IgM. Analysis of the IgG subclasses produced by 10 patients with IgG-secreting $B$ cells revealed that IgG $_{4}$ was the most affected subclass, followed by $\operatorname{IgG}_{2}$; synthesis of $\mathrm{IgG}_{3}$ and $\mathrm{IgG}_{1}$ remained normal. Similarly, in the six IgA producing patients, IgA $A_{2}$ was more often affected than IgA The hierarchy of Ig isotype and subclass synthesis corresponds to Ig heavy chain constant region gene location on chromosome 14. Thus, circulating B cells of CVI patients are committed to synthesize one or more Ig isotypes or subclasses, and under proper conditions can proliferate, mature into Ig-secreting cells, and undergo class switch to IgE. (J. Clin. Invest. 1993. 92:1282-1287.) Key words: hypogammaglobulinemia • B cells • anti-CD40 $\mathrm{mAb} \cdot$ interleukin
\end{abstract}

\section{Introduction}

Common variable immunodeficiency $(\mathrm{CVI})^{1}$ is a heterogeneous group of disorders characterized by defective antibody production. Diagnostic criteria include low levels of serum IgG and $\operatorname{IgA}$ and, in most cases, low levels of IgM (1). Although this syndrome is the most frequently observed primary immunodeficiency disease, the molecular and cellular defects responsible for this disorder are poorly understood. Most reports indicate that the majority of CVI-patients have normal numbers of circulating $B$ cells $(1,2)$, implying that hypogammaglobulinemia

Address correspondence to Dr. Shigeaki Nonoyama, Department of Pediatrics, RD-20, School of Medicine, University of Washington, Seattle, WA 98195.

Received for publication 23 November 1992 and in revised form 30 March 1993.

1. Abbreviations used in this paper: CVI, common variable immunodeficiency.

J. Clin. Invest.

(c) The American Society for Clinical Investigation, Inc.

$0021-9738 / 93 / 09 / 1282 / 06 \$ 2.00$

Volume 92, September 1993, 1282-1287 is caused by a failure of B cells to mature into immunoglobulin (Ig) secreting cells. This failure of B cell maturation in CVI may be caused by a lack of appropriate $T$ cell help or by an intrinsic $B$ cell defect. To differentiate these possibilities, a number of investigators have co-cultured $B$ and $T$ cell populations from CVI patients and normal controls in various combinations, using a pokeweed-mitogen-driven system (3-6). Results of these studies are difficult to interpret since the abnormalities observed may have been directly due to allogeneic effects. The availability of new reagents has allowed us to directly induce $B$ cells to proliferate and differentiate into Ig-secreting cells bypassing the need for $\mathrm{T}$ lymphocytes.

Using purified B cells, Clark and Ledbetter found that costimulation with anti- $\mu$ antibody and $\mathrm{a} \mathrm{mAb}$ recognizing the $\mathrm{B}$ cell surface molecule CD40 promotes direct activation and proliferation of B cells (7). This stimulatory effect is increased by the presence in the culture system of murine $L$ cells that are stably expressing human $\mathrm{Fc}$ receptors (CDw32 L cells) (8). If combined with anti-CD40, particular cytokines were shown to enhance $B$ cell proliferation and to induce $B$ cell differentiation and Ig synthesis. For instance, co-stimulation with IL-4 strongly induces anti-CD40 activated B cells to proliferate and to switch to IgE synthesis (8). Long-term cultures of human B cells have been initiated and maintained by the combination of anti-CD40 mAb and IL-4 (9). Whereas the Ig isotype produced by B cells stimulated with anti-CD40 mAb and IL- 4 is mostly IgE, B cells stimulated with anti-CD40 mAb and IL-10 synthesize IgG, IgA, and IgM (10). Since these newly developed culture systems do not require the presence of $T$ cells, they provide a useful experimental tool to evaluate B cell function in patients with CVI and to gain new insight into the cause of their hypogammaglobulinemia.

\section{Methods}

Patients. All 22 patients with CVI ( 12 males, 10 females, ages 13-75 yr) selected for the study had low or undetectable levels of serum IgG, IgA, and IgM, with the exception of two patients, one with normal IgA and one with normal IgM concentration. The arithmetic mean serum IgG level of CVI patients was $99 \mathrm{mg} / \mathrm{dl}$ (range: 0-390). Mean IgA level of 21 patients with abnormal $\mathrm{IgA}$ was $0.6 \mathrm{mg} / \mathrm{dl}$ (range: $0-9$ ), and mean IgM level of 21 patients with abnormal IgM was $13 \mathrm{mg} / \mathrm{dl}$ (range: 0-39). Serum IgE was detectable in none of the patient sera $(<0.7 \mathrm{ng} / \mathrm{ml})$. Serum Ig concentrations were measured before treatment of intravenous immunoglobulin was initiated. CD20(+) B cells were present in normal numbers in all patients. 16 healthy adult volunteers were studied simultaneously and served as normal controls.

Reagents. Purified anti-CD40 mAb (G28-5 ( $\left.\left.\operatorname{IgG}_{1}\right)\right)$ was kindly provided by Dr. E. Clark, University of Washington, Seattle, WA. Purified human rIL-4 and rIL-10 were obtained from DNAX Research Institute, Palo Alto, CA. The CDw32/Fc $\gamma$ RII-transfected Ltk ${ }^{-}$cell line (CDw32 L cells) (11) was obtained through American Type Culture Collection, Rockville, MD.

Cell preparations. Peripheral blood mononuclear cells were prepared by the Ficoll-Hypaque gradient method (Winthrop Pharmaceu- 
ticals, New York, NY). T cells were removed from mononuclear cells by twice rosetting with aminoethylisothiuronium bromide (AET) (Sigma Chemical Co., St. Louis, MO) treated sheep red blood cells. Natural killer cells and monocytes were removed by the treatment with $5 \mathrm{mM}$ L-leucine methyl ester hydrochloride (Sigma Chemical Co.) in serum-free RPMI 1640 as described (12). The B cell-enriched populations obtained consisted of more than $90 \%$ B cells $\left(\mathrm{CD}^{+} 0^{+}\right)$and less than $1 \% \mathrm{~T}$ cells $\left(\mathrm{CD}^{+}\right)$.

Stimulation of $B$ cells with anti-CD40 $\mathrm{mAb}$ and cytokines. To induce $B$ cell proliferation, $2.5 \times 10^{4}$ purified $B$ cells were cultured for $4 \mathrm{~d}$ in 96-well round bottom microculture plates at a final volume of $200 \mu \mathrm{l}$ of RPMI 1640 supplemented with $10 \%$ FCS (Hyclone, Logan, UT), 2 $\mathrm{mM}$ glutamine, $50 \mathrm{U} / \mathrm{ml}$ penicillin, and $50 \mu \mathrm{g} / \mathrm{ml}$ of streptomycin (complete medium) with anti-CD40 mAb G28-5 $(1 \mu \mathrm{g} / \mathrm{ml})$ and IL-4 $(100 \mathrm{U} / \mathrm{ml})$ followed by a $16-\mathrm{h}$ pulse with $1 \mu \mathrm{Ci}\left[{ }^{3} \mathrm{H}\right]$ thymidine. To induce Ig production, $2.5 \times 10^{4}$ purified $\mathrm{B}$ cells per well were cultured in 96-well round bottom microculture plates in $200 \mu$ l of complete medium in the presence of $2.5 \times 10^{4}$ irradiated $(7,500 \mathrm{rad}) \mathrm{CDw} 32 \mathrm{~L}$ cells, mAb G28-5 (final concentration $1 \mu \mathrm{g} / \mathrm{ml}$ ), IL-4 $(100 \mathrm{U} / \mathrm{ml}$ ) or IL-10 $(10 \mathrm{ng} / \mathrm{ml})$. After $12 \mathrm{~d}$ of culture, supernatants were collected and tested for Ig levels.

Immunoglobulin determination. The concentrations of IgG, IgA, IgM, IgE, IgG subclasses, and IgA subclasses in the sera of CVI patients or in the supernatants of cultured cells were measured by ELISA. For IgG, IgM, IgA, and IgE determination (12), 96-well microculture plates were coated with either goat anti-human IgG, IgA, or IgM (Cappel Laboratories, West Chester, PA) or a mixture of equal amounts of

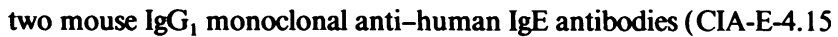
and CIA-E-7.12, kindly provided by Dr. Andrew Saxon, University of California, Los Angeles, CA) in appropriate dilution and kept overnight at $4^{\circ} \mathrm{C}$. After blocking the wells with PBS containing $1 \%$ BSA, serially diluted test samples or standards were added to each well and cultured at $37^{\circ} \mathrm{C}$ for $2 \mathrm{~h}$. Purified human IgG, IgA, and IgM standards were purchased from Kent Laboratory (Kent, WA). IgE standard was purchased from Pharmacia AB, Uppsala, Sweden. After washing, secondary antibodies were added and cultured for $2 \mathrm{~h}$ at $37^{\circ} \mathrm{C}$. Secondary antibodies used were as follows: alkaline phosphatase conjugated goat anti-human IgG (Cappel Laboratories), alkaline phosphatase conjugated goat anti-human IgA (Sigma Chemical Co.), alkaline phosphatase conjugated goat anti-human IgM (Sigma Chemical Co.), or biotin conjugated goat anti-human IgE (Kirkegaard and Perry Laboratories, Gaithersburg, MD). For IgE measurement, alkaline phosphatase conjugated extravidin (Sigma Chemical Co.) was also used. Substrate solution containing $p$-nitrophenyl phosphate disodium (Sigma Chemical Co.) was prepared at a concentration of $1 \mathrm{mg} / \mathrm{ml}$ in carbonate buffer, pH 9.8, with $10 \mathrm{mM} \mathrm{MgCl} 6 \mathrm{H}_{2} \mathrm{O}$. To measure IgG subclasses, 96-well microculture plates were coated with subclass specific $\mathrm{mAbs}$ as follows: HP6069 and HP 6001 (at equal volumes) for IgG Ig $_{1}$ HP6002 and HP6014 for $\operatorname{IgG}_{2}$, HP6050 and HP6047 for $\mathrm{IgG}_{3}$, and HP6023 and HP6025 for $\mathrm{IgG}_{4}$. These mAbs were purchased from Calbiochem-Novabiochem Corp., La Jolla, CA. After blocking the wells with PBS containing $1 \% \mathrm{BSA}$, serially diluted culture supernatants or standards (World Health Organization standards 67/97 obtained from Centers for Disease Control, Atlanta, GA) were incubated for $4 \mathrm{~h}$ at $37^{\circ} \mathrm{C}$. After washing, peroxidase conjugated goat anti-human IgG (Boehringer Mannheim Biochemicals, Indianapolis, IN) was added to the wells. After 2-h incubation and washing, citrate buffer containing 2,2'-azinobis (3-ethylbenzthiazoline-6-sulfonic acid) (Sigma Chemical Co.) and $\mathrm{H}_{2} \mathrm{O}_{2}$ (Parke-Davis, Morris Plains, NJ) was added. For IgA subclass measurements, microculture plates were coated with mAbs Alc and HP 6103 for $\operatorname{Ig} A_{1}$, and with 14-3-26 and HP6109 for IgA $A_{2}$. These monoclonal anti-human IgA subclass specific antibodies were kindly provided by Dr. M. E. Conley, University of Tennesse, Memphis, TN, and the late Dr. C. B. Reimer, Centers for Disease Control, Atlanta, GA. Human $\operatorname{Ig} A_{1}$ and $\operatorname{IgA}_{2}$ standard were purchased from Calbiochem-Novabiochem Corp. For secondary antibody, alkaline phosphatase conjugated goat anti-human IgA (Cappel Laboratories) was used. The optical density was determined with an automated ELISA plate reader (Beckman Instruments, Inc., Fullerton, CA).

\section{Results}

$B$ cell proliferation. Purified B cells from all CVI patients ( $n$ $=22)$ and normal controls $(n=16)$ showed increased $\left[{ }^{3} \mathrm{H}\right]-$ thymidine uptake if cultured with anti-CD40 and IL-4 (Fig. 1). The geometric mean thymidine uptake observed in stimulated normal B cells was $8,090 \mathrm{cpm}$ (95\% confidence interval, $1,324-49,431 \mathrm{cpm}) \cdot\left[{ }^{3} \mathrm{H}\right]$ Thymidine uptake observed in stimulated CVI-B cells was similar to controls $(P=0.96, t$ test $)$ with a geometric mean of $7,726 \mathrm{cpm}$ (range: $1,428-41,347$ ).

IgE production. As shown in Fig. 2, purified B cells from all normal subjects $(n=16)$ produced $\mathrm{IgE}$ if cultured for $12 \mathrm{~d}$ in the presence of anti-CD40 mAb and IL-4 (geometric mean IgE $=4,236 \mathrm{pg} / \mathrm{ml}, 95 \%$ confidence interval, $104-171,001 \mathrm{pg} /$ $\mathrm{ml}$ ). Using the same culture system, B cells from all CVI patients $(n=22)$ produced similar amounts of IgE (geometric mean $=3,147 \mathrm{pg} / \mathrm{ml}$, range, $248-29,888 \mathrm{pg} / \mathrm{ml})(P=0.26, t$ test). Without stimulation, B cells from CVI patients failed to produce detectable levels of $\operatorname{IgE}(<100 \mathrm{pg} / \mathrm{ml})$, while B cells from 11 of 16 normal controls produced detectable IgE.

Production of $\operatorname{IgG}, \operatorname{IgA}$, and IgM with anti-CD40 and IL10. In the absence of in vitro stimulation, B cells from 7 of 22 CVI patients produced detectable levels of IgM, 1 patient produced detectable levels of $\operatorname{IgA}$, and 1 patient produced detectable levels of IgG. In contrast, unstimulated B cells from most normal subjects produced detectable levels of IgA, IgG, and IgM (Fig. 3).

If stimulated with anti-CD40 and IL-10, B cells from all normal subjects showed a marked increase in the synthesis of IgG, IgA, and IgM. Individual values, geometric means, and 95\% confidence intervals are indicated in Fig. 3.

B cells from all CVI patients studied $(n=22)$, if cultured with anti-CD40 and IL-10, produced at least detectable levels of IgM. Based on the isotypes synthesized in vitro by stimulated B cells, the 22 CVI patients were divided into 4 groups. Stimulated B cells from patients in group A $(n=6)$ produced IgA, IgG, and IgM at normal concentrations ( range: 170-3,538 $\mathrm{ng} / \mathrm{ml}(\operatorname{IgA}), 142-1,053 \mathrm{ng} / \mathrm{ml}(\mathrm{IgG}), 845-29,867 \mathrm{ng} / \mathrm{ml}$ $(\operatorname{IgM}))$. In group $\mathrm{B}(n=4)$, the concentrations of $\operatorname{IgG}$ and IgM synthesized by cultured B cells were normal (range: 111-283 $\mathrm{ng} / \mathrm{ml}$ (IgG), 340-2,279 ng/ml (IgM)), but IgA levels were below 2 SD of the normal. B cells from group $\mathrm{C}(n=8)$ pro-
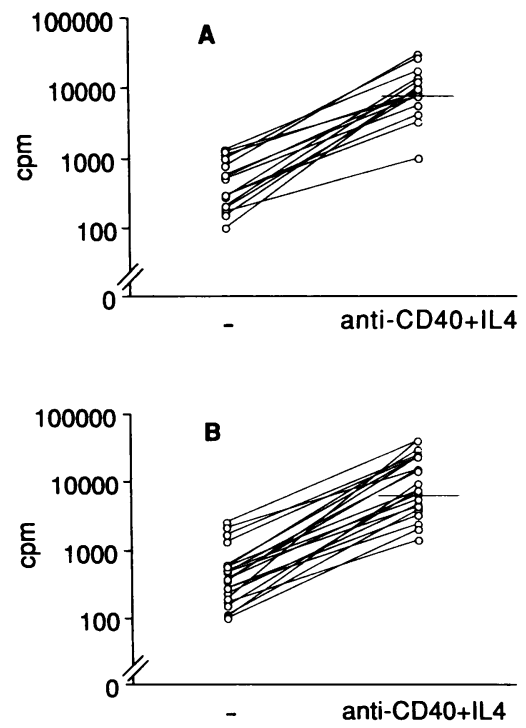

Figure 1. Proliferative responses of $\mathrm{B}$ cells from $(A)$ normal controls $(n=16)$ and $(B)$ CVI patients $(n=22)$. Purified B cells $(5$ $\times 10^{4}$ ) were cultured in triplicates with or without mAb G28-5 (1 $\mu \mathrm{g} /$ $\mathrm{ml})$ and IL-4 ( $100 \mathrm{U} /$ $\mathrm{ml}$ ) for $4 \mathrm{~d}$. After a 16-h $\left[{ }^{3} \mathrm{H}\right]$ thymidine pulse, proliferation was estimated and expressed as cpm. Results are means of triplicates. Horizontal bars indicate geometric mean of each group. 


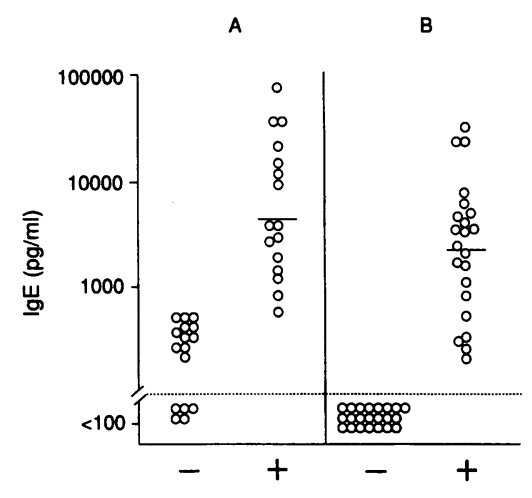

Figure 2. In vitro IgE production by $\mathrm{B}$ cells from $(A)$ normal controls $(n=16)$ and $(B)$ CVI patients $(n=22)$ Purified B cells $(5$ $\times 10^{4}$ ) were cultured in triplicates with $(+)$ or without (-) mAb G28$5(1 \mu \mathrm{g} / \mathrm{ml})$ and IL-4 $(100 \mathrm{U} / \mathrm{ml})$ on irradiated $(7,500 \mathrm{rad})$ CDw32 L cells $(5$ $\left.\times 10^{3}\right)$. Supernatants were collected on day 12 and IgE levels were measured by ELISA. Horizontal bars indicate geometric mean of each group. Dotted line indicates lower limits of detection $(100 \mathrm{pg} / \mathrm{ml})$.

duced normal amounts of IgM (range: $248-7,219 \mathrm{ng} / \mathrm{ml}$ ); but IgG and IgA concentrations were below detectable levels $(<40$ $\mathrm{ng} / \mathrm{ml})$. In group $\mathrm{D}(n=4)$, only IgM at levels below $2 \mathrm{SD}$ of normal controls (range: $62-109 \mathrm{ng} / \mathrm{ml}$ ) was detectable.
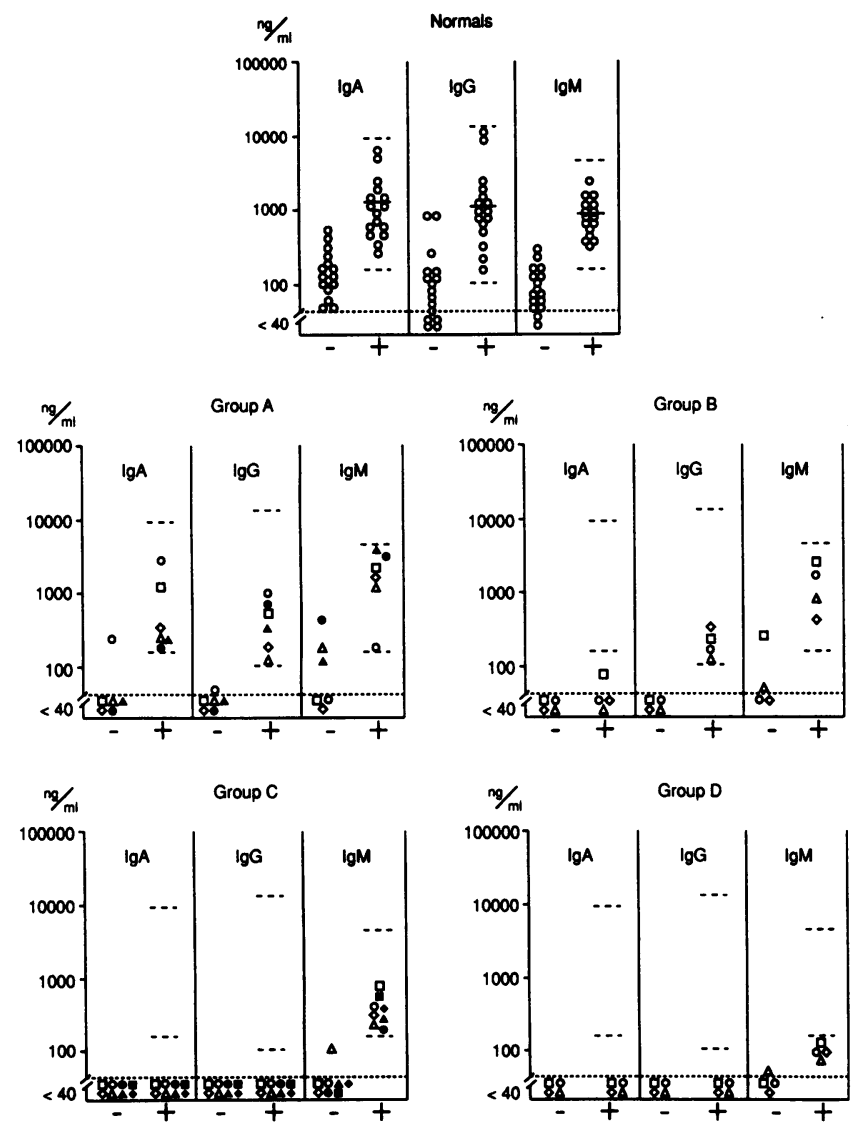

Figure 3. In vitro IgA, IgG, and IgM production by B cells from normal controls $(n=16)$ and CVI patients (Group $A-D)$. B cells ( 5 $\left.\times 10^{4}\right)$ were cultured with (+) or without $(-) \mathrm{mAb}$ G28-5 $(1 \mu \mathrm{g} / \mathrm{ml})$ and IL-10 $(10 \mathrm{ng} / \mathrm{ml})$ on irradiated $(7,500 \mathrm{rad}) \mathrm{CDw} 32 \mathrm{~L}$ cells $(5$ $\times 10^{3}$ ). Supernatants were collected on day 12 and IgA, IgG, and IgM were measured by ELISA. Solid lines and dashed lines indicate geometric mean and $95 \%$ confidence intervals, respectively, determined for normal controls. Dotted line indicates lower limits of detection $(40 \mathrm{ng} / \mathrm{ml})$. CVI patients were pooled into 4 groups $(A-D)$ based on the Ig isotypes synthesized in vitro by stimulated B cells.
In vitro Ig synthesis could frequently be induced in B cells derived from CVI patients who had undetectable serum Ig. Of the six CVI patients with B cells that produced normal amounts of IgA in vitro, five did not have measurable concentrations of serum IgA $(<5 \mathrm{mg} / \mathrm{dl})$. Of the $10 \mathrm{CVI}$ patients producing IgG in vitro, 3 had undetectable levels of serum IgG $(<5 \mathrm{mg} / \mathrm{dl})$. Of 18 patients producing IgM at normal concentration, 3 had undetectable serum IgM $(<5 \mathrm{mg} / \mathrm{dl})$. No significant correlation was found between serum Ig concentration and in vitro $\mathrm{Ig}$ production.

IgG and IgA subclasses. IgG subclasses were determined in culture supernatants from normal controls and from CVI patients whose isolated B cells produced IgG in response to antiCD40 and IL-10 (group A and group B). As shown in Fig. 4, $\mathrm{IgG}_{4}$ production was affected more often than $\mathrm{IgG}_{2}$ production, and group $B$ was more affected than group $A$. $\operatorname{IgG}_{1}$ and $\mathrm{IgG}_{3}$ production by patients from group $\mathrm{A}$ and $\mathrm{B}$ was not different from the normal controls. $B$ cells from all patients in group B (4/4) produced decreased amounts of $\mathrm{IgG}_{2}$ and $\mathrm{IgG}_{4}$. B cells from three of six patients in group $A$ showed decreased IgG $_{4}$ production, and only one showed decreased $\mathrm{IgG}_{2}$ production, who also had decreased $\mathrm{IgG}_{4}$ production.
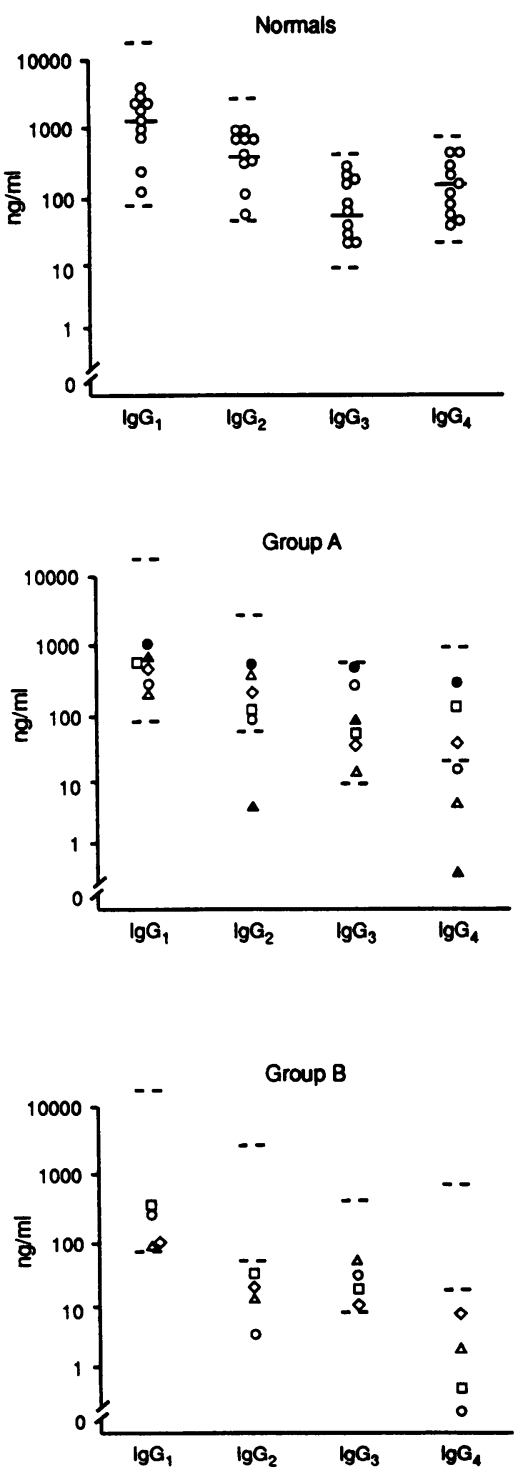

Figure 4. In vitro IgG subclass production by B cells from normal controls $(n=9)$ and CVI patients in group $A$ and $\mathrm{B}(n=10)$. B cells were cultured as described in the legend for Fig. 3. IgG subclasses were measured by ELISA. Solid lines and dashed lines indicate geometric mean and 95\% confidence intervals, respectively, determined for normal controls. 
IgA subclasses were determined in the supernatant of B cell cultures obtained from patients classified as group A (Fig. 5). $\mathrm{IgA}_{2}$ production was below $2 \mathrm{SD}$ of normal controls in two of the six patients, while $\operatorname{Ig} \mathrm{A}_{1}$ production was normal in all six patients, including one patient who had decreased $\mathrm{IgG}_{2}$ production. Of the two patients with low $\operatorname{IgA}_{2}$ production, one had decreased $\mathrm{IgG}_{2}$ and $\mathrm{IgG}_{4}$ production, and one had normal $\mathrm{IgG}_{2}$ and decreased $\mathrm{IgG}_{4}$ production. With one exception (a patient with low $\mathrm{IgG}_{4}$ but normal $\mathrm{IgA}_{2}$ production), the extent of $\mathrm{Ig}$ isotype/ subclass abnormalities observed in CVI patients corresponds with the order of Ig heavy chain constant region gene location on chromosome 14.

\section{Discussion}

In this study, we selected two schemes to assess peripheral blood B cell function in CVI patients, who, although hypogammaglobulinemic, had normal numbers of circulating B cells. B cell proliferation and IgE synthesis was induced by co-culture with anti-CD40 and IL-4, and immunoglobulin (IgG, IgA, and IgM) synthesis was initiated by exposing $B$ cells in vitro to anti-CD40 and IL-10 in the presence of CDw32 L cells. These combinations are known to provide the most effective stimulation for $B$ cell growth and differentiation $(8,10)$ in the absence of $\mathrm{T}$ cells.

Proliferation of CVI-B cells in response to stimulation with anti-CD40 and IL-4 was comparable to B cells from normal controls, suggesting that CVI-B cells receiving appropriate signals will respond with polyclonal proliferation. The same combination of reagents induced $B$ cells to synthesize amounts of IgE comparable to that synthesized by normal control B cells in vitro. Stimulation with anti-CD40 and IL-4 is known to induce class switch to IgE in noncommitted B cells (9). Since none of the CVI patients had detectable serum IgE or produced IgE without stimulation in vitro, it is likely that the exposure of

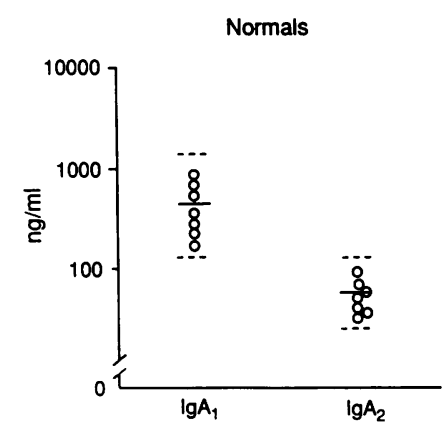

Figure 5. In vitro IgA subclass production by B cells from normal controls $(n=6)$ and Group A

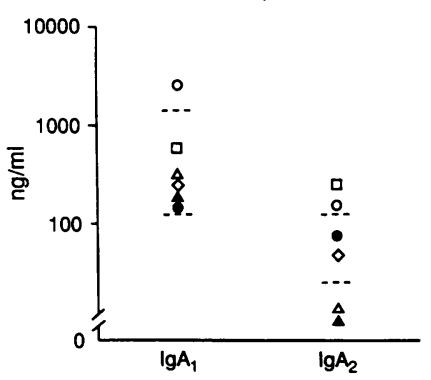

B cells to anti-CD40 and IL-4 resulted in heavy chain switching and secretion of IgE.

Addition of IL-10 to anti-CD40-activated B cells induced the in vitro synthesis of IgM by cells from all CVI patients. Four different patterns of Ig isotype synthesis could be identified (Fig. 3, Table I). Group A produced normal amounts of IgM, IgG, and IgA, group B produced normal amounts of IgM and IgG, and group $C$ secreted IgM at normal concentration but failed to synthesize detectable IgA and IgG. In group D, B cells were limited to the production of low concentration of IgM. These findings suggest a hierarchy in the Ig isotypes secreted by CVI-B cells under our experimental conditions. IgA synthesis is more likely affected than the synthesis of IgG; IgM is affected the least and produced by B cells from all CVI patients. This hierarchy represents the order of heavy-chain constant region genes on chromosome 14. The abnormalities in IgG and IgA subclass production further support this observation (Figs. 4 and 5 ). $\operatorname{IgG}_{3}$ and $\operatorname{IgG}_{1}$ synthesis was conserved, and $\operatorname{IgG}_{2}$ and $\mathrm{IgG}_{4}$ synthesis was frequently deficient, reflecting the location of $\gamma 3$ and $\gamma 1$ "upstream" and $\gamma 2$ and $\gamma 4$ "downstream". $\operatorname{Ig} A_{2}$ was more frequently affected than $\operatorname{IgA}_{1}$, which corresponds to the finding that $\alpha_{1}$ is located upstream of $\alpha_{2}$.

The most likely explanation for the defective isotype production is a lack of circulating B cells committed to the isotypes. Patients within group A have circulating B cells already switched in vivo to IgA, IgG, and IgM; those in group B have circulating B cells committed to IgG and IgM; and patients in groups $\mathrm{C}$ and D have circulating B cells committed to IgM only. This explanation is consistent with the notion that stimulation with anti-CD40 and IL-10 does not induce switching but drives already committed B cells to Ig secreting cells (13). Unresponsiveness to IL-10 by CVI-B cell is not a likely explanation, since all CVI-B cells produced at least IgM, following stimulation with anti-CD40 and IL-10.

Whether the lack of committed B cells to certain isotypes and subclasses is due to an intrinsic $B$ cell defect or to a primary $T$ cell abnormality cannot be determined with certainty. However, the observation that B cells from all CVI patients studied produced amounts of IgE comparable to normal B cells if cultured in the presence of anti-CD40 and IL-4, supports the hypothesis that CVI-B cells are capable of class switching if an appropriate signal is provided. The recent observation that low molecular weight B cell growth factor, which is produced by lectin-activated $T$ cells, can induce B cells from patients with immunodeficiency to secrete IgG and IgA in vitro (14) further supports our hypothesis. The demonstration that $\mathrm{T}$ lymphocytes from a subset of CVI patients, if optimally stimulated in vitro, produced decreased amounts of lymphokines (15-17) suggests that the B cell dysfunction observed in our CVI patients may be due to abnormal in vivo production of lymphokines necessary to initiate the process of heavy chain switching. Examination of cytokines involved in the induction of class switching will further clarify if a primary $T$ cell defect plays a major role in the pathogenesis of CVI.

B cell proliferation in CVI has been examined by other investigators and often found to be defective. Of a group of 15 CVI patients, Saiki et al. found 5 whose B cells failed to proliferate in response to SAC or anti- $\mu$ antibody (18). Similarly, Saxon et al. reported that 3 of 14 CVI patients had depressed proliferative responses to SAC, to anti- $\mu$ antibody combined with BCGF or to PMA (19). Consistent with our results, Bryant and co-workers demonstrated normal proliferative re- 
Table I. Summary of the In Vitro Function of B Cells from CVI Patients

\begin{tabular}{|c|c|c|c|c|c|c|}
\hline CVI Group & Numbers (\%) & Proliferation* & $\operatorname{IgE}^{*}$ & $\operatorname{IgM}^{\ddagger}$ & $\mathrm{IgG}^{\ddagger}$ & $\operatorname{IgA}^{\ddagger}$ \\
\hline Group A & $6(27.3)$ & + & + & + & + & + \\
\hline Group B & $4(18.2)$ & + & + & + & + & - \\
\hline Group C & $8(36.3)$ & + & + & + & - & - \\
\hline Group D & $4(18.2)$ & + & + & \pm & - & - \\
\hline
\end{tabular}

+ , normal levels; \pm , decreased levels; - , undetectable levels.

* $B$ cells were stimulated with anti-CD40 and IL-4, and proliferation and in vitro IgE synthesis was determined.

* B cells were stimulated with anti-CD40 and IL-10, and in vitro Ig synthesis was measured.

sponses of B cells from CVI patients stimulated with anti- $\mu$ and IL-2 (20). Abnormal in vitro Ig synthesis by CVI-B cells was reported by several investigators. Franz et al. observed that B cells from one third $(26 / 78)$ of CVI patients produced normal amounts of IgM and IgG, one third produced only IgM at low concentration, and one third failed to synthesize either IgM or IgG, when cultured in the presence of anti- $\mu$ and IL-2. This abnormality could not be reversed by direct activation of protein kinase $C$ with PMA and ionophore and simultaneous exposure to IL-2 or IL-4 (21). Saxon and co-worker reported that using T cell-replacing factor and PMA to induce CVI-B cells into Ig-secreting cells, B cells from 14 of $17 \mathrm{CVI}$ patients failed to respond (19). In a study by Mayer et al., only 11 of $25 \mathrm{CVI}$ patients generated Ig plaque-forming cells. 5 of the 11 responders generated IgG-secreting plaque-forming cells and only 1 CVI patient had IgA-secreting plaque-forming cells if B cells were stimulated with differentiation factor obtained from $\mathrm{T}$ cell hybridomas (22). The observation of Pasterelli et al. that PBL of six of eight CVI patients failed to produce measurable IgE if cultured in the presence of IL-4 (23) may well be due to abnormal $\mathrm{T}$ cell function.

The discrepancies between our results and those of others can be explained by the more effective stimulation of $B$ cells with anti-CD40 and IL-4 or IL-10 in the presence of CDw32 L cells. Alternatively, since CVI is a heterogeneous group, the defect may vary within the study populations. However, since 20 of 22 patients had low or undetectable levels of serum Ig, it is not likely that our patient population represented a type of CVI that was less affected than that of other groups.

The observation that B cells from CVI patients including those with undetectable serum Ig produced normal levels of one or more isotypes if cultured with anti-CD40 and IL-10 suggests that CVI-B cells have the ability to mature into Ig secreting cells if appropriate signals are provided. We hypothesized that the profound hypogammaglobulinemia characteristic for CVI patients may, in part, be due to defective expression of the CD40 ligand on T cells (24) and/or defective production of IL-10. The observation by Ishida et al. that treatment of normal mice with neutralizing anti-IL-10 mAb results in decreased serum concentration of $\operatorname{IgM}$ and $\operatorname{IgA}(25,26)$ supports this hypothesis. With the proper reagents available, this hypothesis can now be tested.

\section{Acknowledgments}

We wish to thank Dr. Kevin W. Moore for allowing us to use CDw32 L cells.
This work was supported by the National Institutes of Health grant HD-17427. A portion of this work was conducted through the Clinical Research Center of the University of Washington, which is the recipient of National Institutes of Health grant RR-37.

\section{References}

1. World Health Organization Scientific Group. 1992. Primary immunodeficiency diseases. Immunodefic. Rev. 3:195-236.

2. Cooper, M. D., and M. D. Lawton. 1972. Circulating B-cells in patients with immunodeficiency. Am. J. Pathol. 69:513-528.

3. De La Concha, E. G., G. Oldham, A. D. B. Webster, G. L. Asherson, and T. A. E. Platts-Mills. 1977. Quantitative measurements of T-and B-cells function in 'variable' primary hypogammaglobulinemia: evidence for a consistent B-cel defect. Clin. Exp. Immunol. 27:208-215.

4. Waldmann, T. A., M. Durm, S. Broder, M. Blackman, R. M. Blaese, and S Strober. 1974. Role of suppressor $T$ cells in pathogenesis of common variable hypogammaglobulinaemia. Lancet. ii:609-613.

5. Siegal, F. P., M. Siegal, and R. A. Good. 1976. Suppression of B-cell differentiation by leukocytes from hypogammaglobulinemic patients. J. Clin. Invest. 58:109-122.

6. Siegal, F. P., M. Siegal, and R. A. Good. 1978. Role of helper, suppressor and B-cell defects in the pathogenesis of the hypogammaglobulinemias. $N$. Engl. J. Med. 299:172-178.

7. Clark, E. D., and J. A. Ledbetter. 1986. Activation of B cells mediated through two distinct cell surface differentiation antigens, Bp35 and Bp50. Proc. Natl. Acad. Sci. USA. 83:4494-4498.

8. Banchereau, J., P. D. Paoli, A. Valle, E. Garcia, and F. Rousset. 1991 Long-term human B cell lines dependent on interleukin-4 and antibody to CD40. Science (Wash. DC). 252:70-72.

9. Shapira, S. K., D. Vercelli, H. H. Jabara, S. M. Fu, and R. S. Geha. 1992. Molecular analysis of the induction of immunoglobulin E synthesis in human B cells by interleukin 4 and engagement of CD40 antigen. J. Exp. Med. 175:289292.

10. Rousset, F., E. Garcia, T. Defrance, C. Peronne, N. Vezzio, D. H. Hsu, R. Kastelein, K. W. Moore, and J. Banchereau. 1992. Interleukin 10 is a potent growth and differentiation factor for activated human B lymphocytes. Proc. Natl. Acad. Sci. USA. 89:1890-1893.

11. Pelts, G. A., M. L. Trounstine, and K. W. Moore. 1988. Cloned and expressed human $\mathrm{Fc}$ receptor for IgG mediates anti-CD3 dependent lymphoproliferation. J. Immunol. 141:1891-1896.

12. Zhang, K., E. A. Clark, and A. Saxon. 1991. CD40 stimulation provides an IFN- $\gamma$-independent and IL-4-dependent differentiation signal directly to human B cells for IgE production. J. Immunol. 146:1836-1842.

13. Defrance, T., B. Vanbervliet, F. Brière, I. Durand, F. Rousset, and J. Banchereau. 1992. Interleukin 10 and transforming growth factor $B$ cooperate to induce anti-CD40-activated naive human B cells to secrete immunoglobulin A. J. Exp. Med. 175:671-681.

14. Bertolini, J. N., J. Bertolini, E. Thean, and E. M. Benson. 1992. Human low molecular weight B cell growth factor induces surface IgM+/A- B cells to express and secrete IgA. J. Immunol. 149:1771-1778.

15. Hauber, I., M. B. Fischer, and M. M. Eibl. 1992. Detection of reduced levels of IL-2 and IFN- $\gamma$ transcripts after antigenic stimulation of T cells in CVID patients. Proc. Int. Congr. Immunology 8th, Budapest. Springer-Verlag, Budapest. W-61:374a. (Abstr.)

16. Sneller, M. C., and W. Strober. 1990. Abnormalities of lymphokine gene expression in patients with common variable immunodeficiency. J. Immunol. 144:3762-3769. 
17. Farrington, M. L., D. B. Lewis, and H. D. Ochs. 1992. Lymphokine production and gene expression in patients with common variable immunodeficiency. Fed. Proc. 6:1068a. (Abstr.)

18. Saiki, O., P. Ralph, C. Cunningham-Rundles, and R. A. Good. 1982 Three distinct stages of B-cell defect in common varied immunodeficiency. Proc. Natl. Acad. Sci. USA. 79:6008-6012.

19. Saxon, A., J. V. Giorgi, E. H. Sherr, and J. M. Kagan. 1989. Failure of B cells in common variable immunodeficiency to transit from proliferation to differentiation is associated with altered B cell surface-molecule display. J. Allergy Clin. Immunol. 84:44-55.

20. Bryant, A., N. C. Caliver, E. Toubi, A. D. B. Webster, and J. Farrant 1990. Classification of patients with common variable immunodeficiency by $B$ cell secretion of IgM and IgG in response to anti-IgM and interleukin-2. Clin. Immunol. Immunopathol. 56:239-248.

21. Franz, A., A. Bryant, A. D. B. Webster, and J. Farrant. 1992. Effect of 12,13-phorbol dibutyrate and ionomycin on defective $B$ cells in common variable immunodeficiency. Clin. Exp. Immunol. 87:461-464.
22. Mayer, L., S. M. Fu, C. Cunningham-Rundles, and H. G. Kunkel. 1984. Polyclonal immunoglobulin secretion in patients with common variable immunodeficiency using monoclonal B cell differentiation factors. J. Clin. Invest. $74: 2115-2120$

23. Pastorelli, G., M. G. Roncarolo, C. Peronne, P. A. Tovo, and J. E. De Vries. 1990. The capacity of interleukin-4 to induce in vitro IgE synthesis by $B$ cells of patients with common variable immunodeficiency. Clin. Exp. Immunol. $82: 120-127$

24. Armitage, R. J., W. C. Fanslow, L. Strockbine, T. A. Sato, K. N. Clifford, B. M. Macduff, T. Davis-Smith, C. R. Maliszewski, E. A. Clark, C. A. Smith et al. 1992. Molecular and biological characterization of a murine ligand for CD40. Nature (Lond.). 357:80-82.

25. Ishida, H., R. Hastings, J. Kearney, and M. Howard. 1992. Continuous anti-interleukin 10 antibody administration depletes mice Ly-1 B cells but not conventional B cells. J. Exp. Med. 175:1213-1220.

26. Howard, M., A. O'garra, H. Ishida, R. D. W. Malefyt, and J. De Vries. 1992. Biological properties of Interleukin 10. J. Clin. Immunol. 12:239-247. 